\section{Ecce quam bonum et quam iucundum habitare fratres in unum}

\author{
af seniorforsker Ole Kongsted, Det Kongelige \\ Bibliotek
}

$\mathrm{N}$

år kirkemusikere og liturgikyndige hører indledningen til denne Davids Psalme 133, så ved de, at den liturgiske anvendelse hører de sidste søndage i kirkeåret til; eller rettere gjorde tidligere. Teksten var tidligere Graduale, altså vekselsang, til 28. søndag i kirkeåret. Det er en tekst med betydelige kirkehistoriske, kirkepolitiske og musikhistoriske konnotationer. Renaissancemesteren Ludwig Senfls firstemmige motet til denne tekst var musikvalget ved åbningen af det verdenshistorisk set betydningsfulde rigsdagsmøde i Augsburg, juni 1530. Budskabet var dengang særdeles aktuelt: kejser og kardinal på den ene side af bordet, de protestantiske fyrster og Wittenbergteologerne - som bekendt uden Martin Luther - på den anden side i forsøget pả at bygge en bro, der på dette tidspunkt ikke lod sig bygge. Teksten - et bibelsk udtryk for broderlig samdrægtighed - har ingensinde mistet sin aktualitet; den er vel i dag sả aktuel som nogensinde. Den danske 1931-oversættelse, priser brødres samvær sålunde: "Se, hvor godt og hvor lifligt er det, naar Brødre bor tilsammen". Den

engelske version fra King James lyder: "Behold, how good and how pleasant it is for brethren to dwell together in unity", mens Luther for egen regning tilføjer et "samdrægtigt", som der ikke er belæg for i de gamle hebraiske og græske tekster: "Siehe wie fein und lieblich ist's daß Brüder einträchtig beieinander wohnen!" Med bemærkning om at Holberg ville have sagt det anderledes: "Forliger Eder, I skabhalse" skal jeg vende tilbage til denne tekst om et øjeblik.

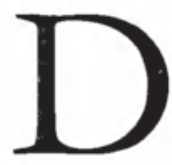
et er i den akademiske verden - ikke mindst den tyske i øvrigt - tradition at fejre prisuddelinger, jubilæer, runde fødselsdage etc. med en såkaldt 'laudatio' - en 'lovsang', en tale, i hvilken 'laudator' anpriser festens genstands fortræffeligheder, omtaler hans liv og værk. Det skal vi her i aften gøre meget kortfattet, dels er der ikke een men to 'festgenstande', dels er der tale om to fremragende forskere, der begge har været meget flittige, hvorfor det kunne blive meget omfattende at omtale deres bedrifter, dels er dette en fødselsdags-

Tale 5. maj 2008 ved fejringen med koncert og overrækkelse af festskrift af de to musikprofessorer John Bergsagels og Heinrich Schwabs runde fødselsdage. koncert, der ikke skal gøres til en akademisk forelæsning, dels har vi fundet en bedre måde at præsentere dem for en 'laudatio' på i denne konkrete sammenhæng.

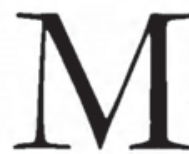
en skal vi kort se pả Bergsagels og Schwabs akademiske karrierer, så er flere forhold i forbindelse med deres faglige 


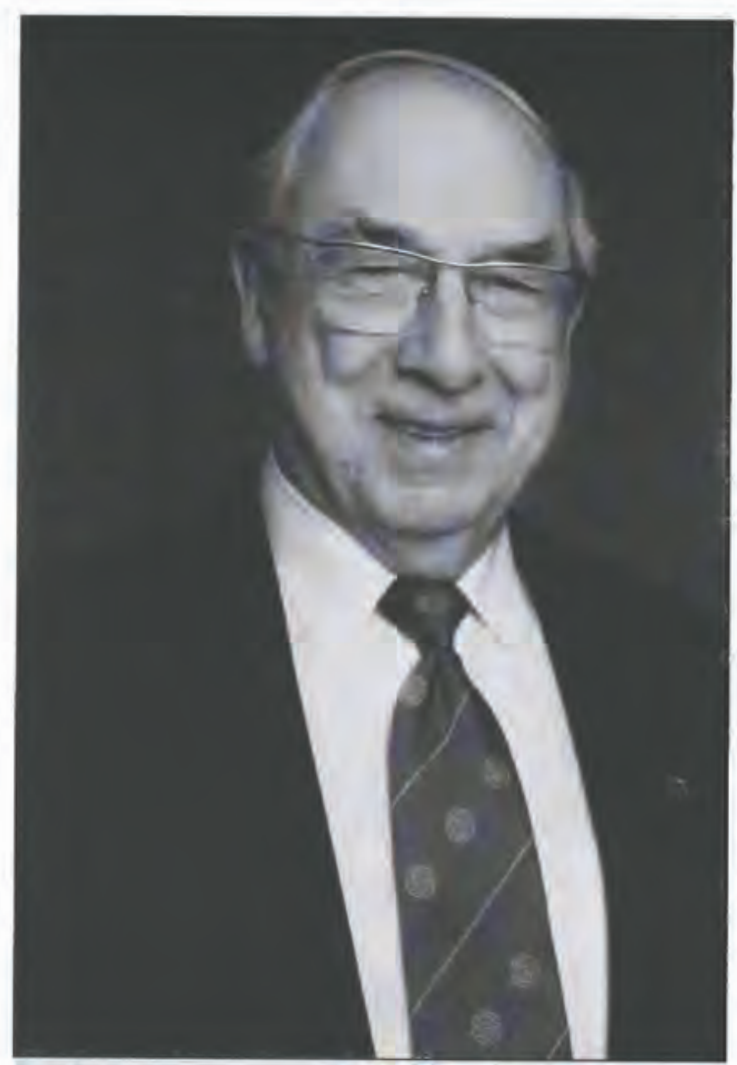

virksomhed forløbet parallelt. Begge er kommet 'udefra' til Danmark, begge hat lagt mange år af deres faglige tilværelse her - med undervisning, forskning og formidling - og begge har senere været opfattet som danskere, når de efterfølgende optrådte i faglig sammenhæng $\mathrm{i}$ udlandet, hvorved de begge - som i øvrigt også en lang række andre lærere ved Musikvidenskabeligt Institut $\mathrm{i}$ årenes løb - har bidraget betydeligt til Københavns Universitets renommé.

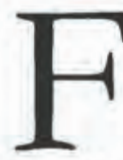

or Bergsagels vedkommende er baggrunden norsk/canadisk, født i Canada af norske forældre. Han blev i 1950 bachelor ved Cornell University efter studier hos Grout og Austin; 1957 blev han doktor på et arbejde vedrørende Ralph Vaughan Williams. 1959 kom han til Oxford som seniorsti-
Professor John Bergsagel.

Bäde John Bergsagel og Heinrich Scbwab har varet samarbejdspartnere for Det Kongelige Bibliotek. For nylig bar begge varet konsulenter for biblioteket $i$ et falles anliggende, en temmelig vigtig sag, - nemlig fremtiden for Carl Nielsen Udgaven og for kommende musikprojekter ved biblioteket. Men bver for sig har de tidligere skerevet artikler i bibliotekets skriftrakker, fungeret som festforelaser eller udstillingsarranger, varet medlem af diverse komiteer, editorial boards og lignende.

For John Bergsagels vedkommende buskes arbejdet med manuskriptet Thott 152, den anonyme messe fra 1590, som forte til udgivelse for 20 àr siden; Middelaldermusikartiklen $i$ Magasin, - og en fremragende festforelesning $i 2004$ i anledning of Musikeafdelingens 125-ärs jubilaum, der som "Henrik Rung - A Feeling for Music Libraries" blev trykt i Det Kongelige Bibliotekes årsskrift Fund og Forskning.

pendiat med udforskningen af de tidlige Tudor-messer som forskningstema. Bergsagel var med til at grundlægge British Academy's serie Early English Church Music, som han var leder for fra 1961-1976. I 1970 kom Bergsagel til Københavns Universitet, hvor han blev professor i 1981 - $\mathrm{i}$ denne stilling sad han indtil 1998, hvor han blev pensioneret. Forskningstemaerne har omfattet et bredt spektrum, hvor engelsk og skandinavisk musik har været centralt placeret, i de senere år ikke mindst temaer fra Middelalder og Renaissance.

Indenfor disse emner er Bergsagel en forsker, der er anerkendt verden over.

Bergsagel er leder af rakken Monumenta Musicae Byzantinae og medlem af Videnskabernes Selskab i Danmark og Norge, og af Academia Europaea. 
Professor Heinrich Schwab.

Heinrich Schwab bar skevevet en artikel om komponisten Kunzen $i$ Fund og Forskning 1995, en Buxtebude-artikel i festskriftet til Musikeafdelingens leder Niels Krabbe i 2006, og tilrettelagde ikke mindst den store Kunzen-udstilling F.L.Ae. Kunzen: Stationen seines Lebens und Wirkens $i 1996$. Udstillingen, som Schwab tog initiativet til, blev forst vist i Det Kongelige Bibliotele, senere i Bibliothele der Hansestadt Lübeck og endelig på ScbleswigHolsteinische Landesbibliothek $i$ Kiel. Et banebrydende arbejde med en komponist, som man mà sige, at det $i$ den grad har lonnet sig at beskaftige sig med, hvad talrige senere artikler og cd'indspilninger bar afsloret. $V$ ed koncerten spilledes bl.a. Kunzens cis-mol-sonate, som Schwab bar wdgivet sammen med Gorm Busk $i$ Det Kongelige Biblioteles regi.

$\mathrm{F}$ Tor Schwabs vedkommende førte studier i Mainz, Kiel og Saarbrücken - ligeledes hos nogle af fagets store navne: Wiora, Abert og Salmen til ansættelse i 1966 i lederstillingen af Landeskundliche Abteilung ved Musikvidenskabeligt Institut i Kiel. Denne stilling havde han til 1998 efter at have habiliteret sig i 1977, hvilket førte til professorudnævnelsen i 1982. I 1998 blev Schwab efterfølger for professor Jan Maegaard ved Københavns Universitet efter tidligere - i 1978/1979 - at have vikarieret i Maegaards stilling, mens denne var på gæestevisit i Californien. Senest har han fra 2002 sammen med Nils Holger Petersen ledet et af Danmarks Grundforskningsfonds alt for få humanistiske forskningsprojekter: Centre for the Study of the Cultural Heritage of Medieval Rituals. Hovedtemaer i hans forskning

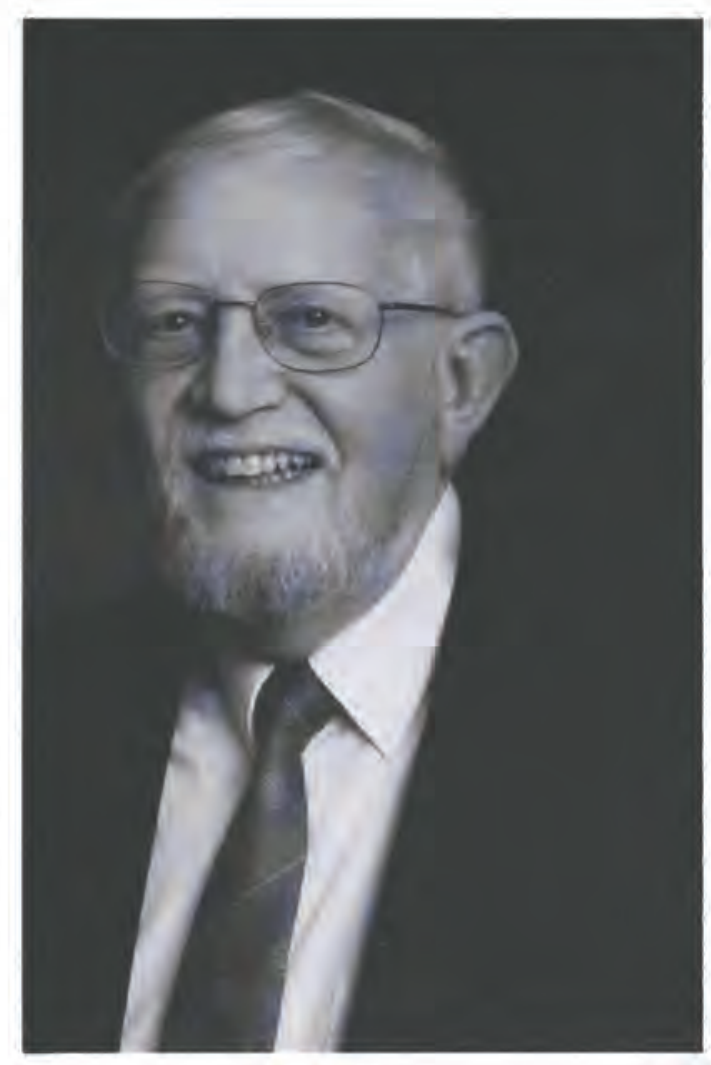

har været lokal- og regionalhistoriske temaer indenfor Østersø-områdets og Skandinaviens musikhistorie, genrexstetik og genrehistorie - først og fremmest indenfor genren Lied. Specielt inden for dette tema må vi sige, at Schwab er en af fagets betydeligste forskere; han har desuden beskæftiget sig med socialhistoriske temaer som f.eks. de banebrydende arbejder vedrørende stadsmusikantinstitutionens historie og også med nyere temaer som f.eks. jazzen i den nyere såkaldte kunstmusik. I de sidste 10-15 år har arbejdet med F.L.Ae. Kunzen stået i centrum; her er vi jo sikkert en del, der håber på, at de publicerede artikler må krones med en brevudgave og en monografi. Schwab er som Bergsagel medlem af det danske Videnskabernes Selskab og af det norske akademi; han er endvidere medlem 


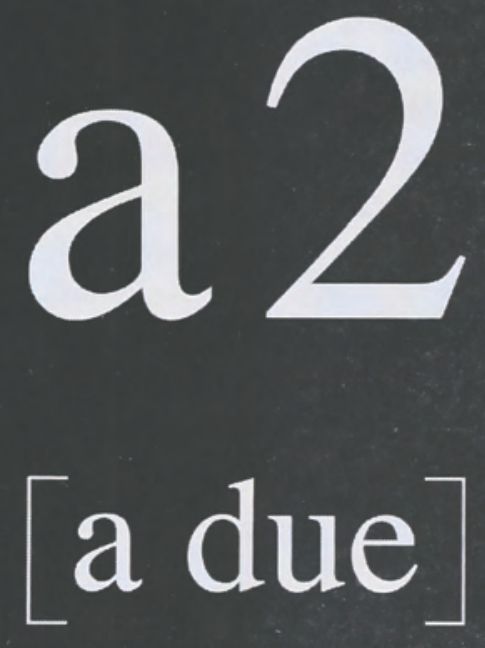

38

FESTSCHRIFT - JOHN D. BERGSAGEL - HEINRICH W. SCHWAB 
af det svenske Musikaliska Akademien. Som Bergsagel er han ligeledes medlem af Academia Europaea.

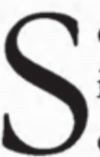

er man de to herrers bibliografier igennem, er det klart for enhver, at det er to meget arbejdsomme forskere, vi fejrer i aften. Vi har med to personer at gøre, der på hver sin måde har styrket dansk musikvidenskab. Vi er en del musikfolk til stede, som med glæde tænker tilbage på den undervisning vi fik af tidligere lærere ved Musikvidenskabeligt Institut, - ingen nævnt, ingen glemt, under forhold, der var en del bedre end tilfældet er for nærværende, - med et antal professorer og lektorer, der desværre nu om stunder er decimeret til ukendelighed. Blandt dem også John Bergsagel, og fra om nogle uger også Heinrich Schwab.

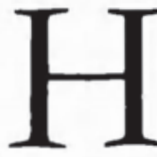
vis man vil tillade 'laudator' et par korte personlige bemærkninger til begge d'herrer som afrunding:

\section{T 7 ære John, Dit musikhistoriske overblik er legendarisk, Henrik 1 [Glahn] sagde altid: "Det ved} John, spørg John ". Din viden om 'early music' har mange misundt Dig, mange haft gavn af. Du har for mange - og altså også for undertegnede - haft stor betydning som samtalepartner. Din sans for detailler i Middelaldermusikken, Dit utrolige overblik over hvem der var hvor hvornår i Renaissancens Europa er udmøntet i Din egen forskning, men det har minsandten også været nyttigt for andre. Kom man til Dig og sagde: "Nu skal Du høre... ", har man altid kunnet regne med Din opmærksomhed, at drøftelsen af et fagligt problem kom hele vejen rundt, at en fortolkningsmulighed altid blev vendt og drejet, at betydningen af en nyopdagelse altid blev forstået, diskuteret og apprecieret umiddelbart - meget ofte således, at der fremkom incitamenter til at gå videre ad dette eller hint spor, som man ikke selv havde tænkt på i forvejen. For mig har det været overordentlig spændende at opleve Din viden, Din fantasi, Din kombinationsevne - kort og godt Din 'næse'.

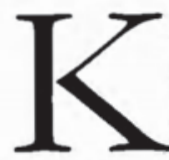
ære Heinrich, ihvorvel du aldrig formelt har været min lærer, har Du haft den gode lærers betydning for mig - på samme måde som mine gamle lærere ved Instituttet, som jeg nævnte tidligere. Talrige studierejser til det sydlige udland igennem omkring 40 år har jævnthen ført mig forbi i begyndelsen Kiel senere forbi "Gasthof zum eingiessenden Schwaben" i Gettorf. En ny spændende opdagelse, et "nyt frimærke til albummet" blev ofte "stukket ind" her først $-i$ sikker forventning om forståelse for sammenhængen og en god samtale vedrørende det pågældende spørgsmål. Disse forventninger blev ingensinde skuffede, og det føler jeg ligeledes anledning til at sige Dig tak for ved denne lejlighed. Din flid er legendarisk. Jeg husker engang, og det er ganske mange år siden, at Du stak mig, hvad jeg troede var særtryk af fyldig artikel i hånden, og jeg tænkte: "Nu har han minsandten skrevet en ny artikel". Det viste sig så ikke at være en ny artikel, med derimod et hefte som indeholdt en Schwab-bibliografi, - altså 


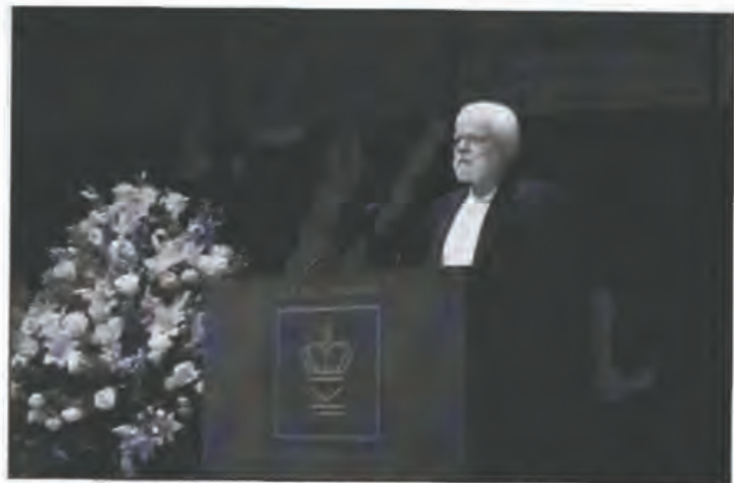

Artiklens forfatter, Ole Kongsted, på talerstolen $i$ Det Kongelige Biblioteles Dronningesal. Fot. Det Kongelige Bibliotek.

en omfattende fortegnelse over alle de skriftlige arbejder, han havde udgivet indtil da.

$\mathrm{J}$ eg skal slutte og springer til sidst tilbage til den tekst, som jeg så uelegant lod hænge i luften i forbindelse oded min indledning: Ecce quam bonum et quam iucundum babitare fratres in unum, - "Se, hvor godt og hvor lifligt er det, naar Brødre bor tilsammen". Urteksterne på hebraisk og græsk betoner Lokaliteten, det faktum at det altså er godt at bo under samme tag - $i$ samme hus. Denne gode tekst har fået sin aktualitet også i denne festlige sammenhæng. På Det Kongelige Bibliotek drøftede man nemlig i 2007 forskellige muligheder for at fejre Jer, da man fandt ud af, at I blev 'runde' samtidig. Man drøftede naturligvis bl.a. muligheden af på akademisk vis at fejre Jer ved at udsende to festskrifter, - men det må jeg desværre sige: dette opgav man hurtigt. Forklaringen er naturligvis den enkle, at bygmestrene [læs: redaktionen] ihukommende tidsperspektivet for 'byggeriet' ikke mente at kunne overskue at bygge både fundament og efterfølgende rejse to 'huse'. Idet vi huskede på det faktum, at brødrene - 'frates' - faktisk ikke blot har levet i luthersk samdrægtighed som kollèger på Musikvidenskabeligt Institut, fandt man en løsning, ved hvilken de in concreto kom til at 'bo under samme tag' - $\mathrm{i}$ kollektiv. - - - Vi valgte naturligvis stordriftens fordele. Sætningen: Se, hvor godt og hvor lifligt det er etc. etc. - blev her let omskrevet: Se, hvor nemt og hvor lønsomt det er, når to brødre kan fejres på én gang!

I deen til et dobbeltfestskrift var direktørens; jeg må indrømme, at jeg ikke havde hørt om noget sådant før, men vi er altså ikke de første, selvom en søgning på ordet "dobbeltfestskrift" på "Google" i sidste uge afslørede den kendte sætning: "Din søgning matchede ikke nogen dokumenter". Til gengxld må man sige, at internettet har vist sig at være hemmelighedskræmmeriets fjende. Det er en god dansk tradition, at man søger at hemmeligholde fremstillingen af festskriftet for festens genstand. Det lykkes i mange tilfælde, skal vist ovenikøbet være lykkedes i forbindelse med de to seneste eksemplarer af slagsen her på stedet, Niels Krabbes 'mursten' fra 2006 og Erland Kolding Nielsens ditto fra 2007. Men hvis man - som jeg gjorde d. 9. april kl. 13,39 - søgte på Bergsagels og Schwabs navne på Google, så kunne man altså to steder i Tyskland bl. a. på Kiels Universitets hjemmeside se: $A$ due, Festschrift, Musical Essays in Honour of John D. Bergsagel and Heinrich W. Schwab/Musikalische Aufsätze zu Ehren von John D. Bergsagel und Heinrich 
W. Schwab. Forklaringen - som må være manglende kendskab til dansk tradition eftersom datoen fremgik af subskriptionsindbydelsen - er vel denne, at Kiels Universitet subskriberede på skriftet, da subskriptionsindbydelsen blev sendt ud, hvorefter man så har lagt meddelelsen om akkvisitionen - før den blev en akkvisition, om jeg så må sige - på internettet. Så for at opnå en 100\%'s effektiv hemmeligholdelse skal vi altså have været heldige.

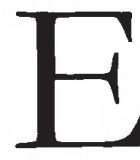
$\mathrm{n}$ lang række kolleger og venner til de to fødselsdagsbørn - faktisk ikke færre end 45 personer - blev derfor bedt om at bidrage til festskriftet med emner, der f. eks. kunne ligge indenfor Bergsagels og Schwabs interessesfærer, som har givet sig udtryk $i$ begges omfattende videnskabelige produktion. Enhver med kendskab til Bergsagels og Schwabs forskning vil forstå, hvor bredt perspektivet og selve idégrundlaget for dette skrift derved kunne blive. Kast blot et blik på de to bibliografier som afslutter denne bog! Som det vil kunne ses af skriftets indholdsfortegnelse, tog mange fagfæller til initiativtagernes store glæde imod invitationen til ved denne lejlighed og på denne måde at fejre John Bergsagel og Heinrich Schwab.

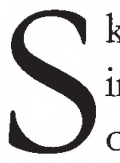
kriftet er blevet til i et samarbejde imellem Københavns Universitet og Det Kongelige Bibliotek, og jeg vil derfor bede direktør Kolding Nielsen på begge institutioners vegne at overrække en ny 'munkesten' i den statelige række fra Det Kongelige Bibliotek til de to fødselarer. 